\author{
Janina Rosiak \\ Ośrodek Doskonalenia Nauczycieli \\ Zachodniopomorskie Centrum Edukacyjne w Szczecinie \\ Piotr Szczypa \\ Zakład Rachunkowości \\ Katedra Zarządzania Finansami \\ Uniwersytet Szczeciński
}

\title{
Proekologiczna edukacja w ksztaltowaniu postaw przedsiębiorczych
}

Aktywizacja gospodarki narodowej wymaga nieustannej edukacji młodych ludzi, kreowania ich postaw, stanowią oni bowiem podstawę rozwoju przyszłego biznesu. Edukacja w przedsiębiorczości powinna podlegać nieustannym zmianom, aby sprostać wszystkim wyzwaniom. Takim wyzwaniem są obecnie: przygotowanie uczniów/studentów do aktywnego życia w warunkach gospodarki rynkowej oraz udzielanie im pomocy w zakresie kształtowania mentalności, postaw i umiejętności przydatnych w ciaggle zmieniających się warunkach. Znajomość podstaw przedsiębiorczości oraz kreowanie przedsiębiorczej jednostki, a także społeczeństwa, w warunkach nasilającej się globalizacji jest niezbędne każdemu człowiekowi, który chce aktywnie włączyć się w światowe procesy rozwoju cywilizacyjnego.

Edukacja w zakresie kreowania postaw przedsiębiorczych to również kształtowanie świadomości zagrożeń, jakie niesie ze sobą dynamiczny rozwój gospodarczy kraju i świata. Uważa się, że jednymi z największych zagrożeń ograniczających możliwości rozwojowe są zagrożenia ekologiczne. Człowiek przedsiębiorczy to człowiek świadomy zagrożeń, wrażliwy na problemy ekologiczne, który widzi zbieżność między interesem ekonomicznym a nowoczesną, efektywną, oszczędną gospodarką uwzględniającą problemy szeroko rozumianej ochrony środowiska.

Świadomość ekologiczną należy rozumieć jako ,świadomość zależności ludzi od pozostałej części przyrody i świadomość wpływu, jaki działalność człowieka wywiera na otaczające środowisko. Świadomość oznacza nie tylko odpowiedni poziom wiedzy, ale również takie jej racjonalne i emocjonalne przyswojenie, które powoduje podejmowanie określonych działań" [Kobyłko (red.) 2000]. W Polsce obserwuje się z roku na rok coraz wyższy stopień świadomości ekologicznej. Niestety, nie zawsze ta świadomość przekłada się na zachowania proekologiczne. Można to zmienić, stosując skuteczny system edukacji proekologicznej, nastawiony na kształtowanie postaw przedsiębiorczych w zakresie zachowań przyjaznych dla środowiska.

W praktyce można zaobserwować cztery stopnie świadomości ekologicznej i przyporządkować im odpowiednie typy konsumenta, których charakterystykę przedstawiono w tab. 1 .

Proces kształtowania postaw przedsiębiorczych powinien być tak ukierunkowany, aby sprzyjał podwyższaniu świadomości i działalności proekologicznej, szczególnie w grupach „czarnych” i ,szarych”, żeby stali się bardziej wrażliwi na potrzeby środowiska przyrodniczego. Dzięki temu będą oni przyjmowali postawy typowe dla grup „szarozielonych” i ,zielonych”. Kształcenie świadomości ekologicznej wymaga edukacji w dziedzinie środowiska przyrodniczego, a także informacji na ten temat na wszystkich szczeblach i formach kształcenia. Edukację proekologiczną jako ważny aspekt kształtowania postaw przedsiębiorczych, można rozpatrywać w szerszej bądź węższej perspektywie. 
Tab. 1. Podejście do problemów ochrony środowiska - poziomy świadomości ekologicznej

\begin{tabular}{|c|c|c|}
\hline $\begin{array}{c}\text { Poziom } \\
\text { świadomości } \\
\text { ekologicznej }\end{array}$ & $\begin{array}{c}\text { Typ } \\
\text { konsumenta }\end{array}$ & Charakterystyka (prezentowane poglądy) \\
\hline 1 & 2 & 3 \\
\hline Niski & $\begin{array}{l}\text { czarny } \\
\text { (podporząd- } \\
\text { kowany } \\
\text { „kultowi } \\
\text { materii”) }\end{array}$ & $\begin{array}{l}\text { - Człowiek, jako istota odrębna i nadrzędna wobec przyrody, ma pra- } \\
\text { wo jej używać, zużywać ją i dowolnie ją kształtować. } \\
\text { - Najważniejsze potrzeby, które muszą być zaspokojone w celu osią- } \\
\text { gnięcia ogólnego dobrobytu społecznego, to pokój, wzrost gospo- } \\
\text { darczy, bezpieczeństwo ekonomiczne, wysoki poziom konsumpcji. } \\
\text { - Zależność zdrowia od stanu środowiska przyrodniczego nie jest za- } \\
\text { leżnością istotną. } \\
\text { - Prowadzony tryb życia nie ma istotnego wpływu na zachorowal- } \\
\text { ność na choroby cywilizacyjne. } \\
\text { - Indywidualne działania jednostki nie wpływają na stan środowiska } \\
\text { przyrodniczego. Za jego degradację odpowiedzialne są przede } \\
\text { wszystkim zakłady przemysłowe. } \\
\text { - Nie ma takiej szkody wyrządzonej przyrodzie przez „technikę”, } \\
\text { której, „technika” nie mogłaby naprawić. } \\
\text { - Istniejący system ochrony środowiska jest wystarczający. }\end{array}$ \\
\hline Przeciętny & $\begin{array}{l}\text { szary } \\
\text { (przeciętny } \\
\text { konsument) }\end{array}$ & $\begin{array}{l}\text { - Człowiek, jako istota najwyżej rozwinięta intelektualnie w świecie } \\
\text { przyrody, ma prawo dowolnie jej używać w celu zaspokojenia swo- } \\
\text { ich potrzeb. } \\
\text { - Najważniejsze potrzeby, które muszą być zaspokojone w celu osią- } \\
\text { gnięcia ogólnego dobrobytu społecznego, to pokój, wzrost gospo- } \\
\text { darczy, bezpieczeństwo ekonomiczne, wysoki poziom konsumpcji, } \\
\text { ochrona przed skażeniem promieniotwórczym i degradacją środowi- } \\
\text { ska na obszarach ekologicznego zagrożenia. } \\
\text { - Zależność zdrowia od stanu środowiska przyrodniczego ujawnia się } \\
\text { jedynie na terenach silnie zdegradowanych. } \\
\text { - Prowadzony tryb życia nieznacznie się przyczynia do zmniejszenia } \\
\text { zachorowalności na choroby cywilizacyjne. } \\
\text { - Indywidualne działania jednostki mają niewielki wpływ na stan śro- } \\
\text { dowiska przyrodniczego. Za jego degradację odpowiedzialne sąprzede } \\
\text { wszystkim zakłady przemysłowe. } \\
\text { - Większość szkód wyrządzonych przyrodzie przez „technikę” } \\
\text { (oprócz skażenia promieniowaniem i klęsk ekologicznych) może } \\
\text { być przez „technike”" naprawiona. } \\
\text { - Istniejący system ochrony środowiska nie jest wystarczający. Do- } \\
\text { skonalenie go to zadanie administracji państwowej. }\end{array}$ \\
\hline Wysoki & \begin{tabular}{|l|} 
szarozielony \\
(chce być \\
postrzegany \\
jako zielony, \\
dba \\
o zdrowie)
\end{tabular} & $\begin{array}{l}\text { - Człowiek, jako część przyrody, zaspokaja w pierwszej kolejności } \\
\text { swoje potrzeby, pamiętając o potrzebach otoczenia. } \\
\text { - Najważniejsze potrzeby, które muszą być zaspokojone w celu osią- } \\
\text { gnięcia ogólnego dobrobytu społecznego, to zapewnienie rozwoju } \\
\text { zrównoważonego (rozwój zrównoważony ekologicznie, ekonomicz- } \\
\text { nie, politycznie i społecznie). } \\
\text { - Zależność zdrowia od stanu środowiska przyrodniczego jest duża. } \\
\text { - Prowadzony tryb życia jest skutecznym sposobem profilaktyki m.in. } \\
\text { chorób cywilizacyjnych. }\end{array}$ \\
\hline
\end{tabular}




\begin{tabular}{|c|c|c|}
\hline 1 & 2 & 3 \\
\hline & & $\begin{array}{l}\text { - Indywidualne działania jednostki mają bardzo duży wpływ na stan } \\
\text { środowiska przyrodniczego. Zanieczyszczenia komunalne i pokon- } \\
\text { sumpcyjne przyczyniają się do degradacji przyrody niemal w takim } \\
\text { samym stopniu, jak zakłady przemysłowe. } \\
\text { - Przyroda stanowi naturalną barierę dla rozwoju naukowo-technicz- } \\
\text { nego z powodu nieodnawialności zasobów. } \\
\text { - Istniejący system ochrony środowiska nie sprzyja prowadzeniu eko- } \\
\text { logicznego stylu życia. Doskonalenie go to zadanie administracji pań- } \\
\text { stwowej oraz instytucji i organizacji społecznych. }\end{array}$ \\
\hline $\begin{array}{l}\text { Bardzo } \\
\text { wysoki }\end{array}$ & $\begin{array}{l}\text { zielony } \\
\text { (chce } \\
\text { zmienić } \\
\text { i zmienia } \\
\text { swój styl } \\
\text { życia, aby } \\
\text { chronić } \\
\text { środowisko) }\end{array}$ & $\begin{array}{l}\text { - Człowiek, będąc integralną częścią przyrody, w równym stopniu } \\
\text { dba o zaspokojenie swoich potrzeb i potrzeb otoczenia. Jeśli to } \\
\text { konieczne, weryfikuje swoje potrzeby i eliminuje te, które naruszaja } \\
\text { równowagę ekologiczną. } \\
\text { - Najważniejsze potrzeby, które muszą być zaspokojone w celu osią- } \\
\text { gnięcia ogólnego dobrobytu społecznego, to zapewnienie rozwoju } \\
\text { zrównoważonego (rozwój zrównoważony ekologicznie, ekonomicz- } \\
\text { nie, politycznie i społecznie). } \\
\text { - Stan środowiska przyrodniczego jest jedną z determinant zdrowia } \\
\text { człowieka. } \\
\text { - Ekologiczny tryb życia jest dla zdrowia człowieka najlepszy. } \\
\text { - Indywidualne działania jednostki mają decydujący wpływ na stan } \\
\text { środowiska przyrodniczego. Gdyby każdy człowiek kierował sie } \\
\text { przede wszystkim dobrem środowiska przyrodniczego (w tym rów- } \\
\text { nież człowieka), nie byłoby problemów ekologicznych. To pojedyn- } \\
\text { czy ludzie tworza społeczeństwa, państwa i rządy, które tymi pań- } \\
\text { stwami rządzą, decydując także o ochronie środowiska. } \\
\text { - Rozwój naukowo-techniczny to jedna z głównych przyczyn degra- } \\
\text { dacji środowiska. Wdrażanie nowych technologii powinno być obję- } \\
\text { te ścisłą kontrolą pod względem oddziaływania na środowisko. Jeśli } \\
\text { człowiek jako gatunek przyrodniczy zagrozi przetrwaniu życia na } \\
\text { planecie, to przyroda obróci się przeciwko niemu. } \\
\text { - Istniejący system ochrony środowiska na ogół utrudnia prowadze- } \\
\text { nie ekologicznego stylu życia. System ochrony środowiska będzie } \\
\text { spełniał swoje zadania, jeżeli jednym z głównych celów każdego } \\
\text { podmiotu gospodarki będzie ochrona środowiska. }\end{array}$ \\
\hline
\end{tabular}

Źródło: opracowanie autorów na podstawie Proekologiczne zarządzanie przedsiębiorstwem, 2000, G. Kobyłko (red.), Wydawnictwo AE we Wrocławiu, Wrocław

W kształceniu postaw przedsiębiorczych ukierunkowanych na działalność proekologiczną biorą udział przede wszystkim [por. Kobyłko (red.) 2000]:

- szkoły - na każdym poziomie kształcenia, odpowiednio do możliwości uczniów, przekazywane są wyniki badań dotyczących zagrożeń środowiska przyrodniczego i możliwości jego ochrony; zmiany w szkolnictwie sprzyjają coraz skuteczniejszej edukacji proekologicznej;

- media lokalne i ogólnopolskie (prasa, radio, telewizja);

- przedsiębiorcy, ludzie biznesu (ich postawa, działania na rzecz ochrony środowiska mogą być wzorcem dla innych);

- Kościół katolicki - ma w Polsce wielką siłę oddziaływania na świadomość społeczeństwa; nauki Kościoła nie kłócą się z poszanowaniem środowiska przyrodniczego i działaniami proekologicznymi; 
- ruch konsumencki - dbałość o jakość produktów i o prawa konsumenta wiąże się bezpośrednio z problemami ekologii i ochrony środowiska.

Tab. 2. Perspektywy podejścia w zakresie edukacji proekologicznej

\begin{tabular}{|l|l|}
\hline \multicolumn{1}{|c|}{ Podejście szerokie } & \multicolumn{1}{c|}{ Podejście wąskie } \\
\hline $\begin{array}{l}\text { Kształcenie rozumiane w szerokim kontekście } \\
\text { powinno uwrażliwiać człowieka na problemy }\end{array}$ & $\begin{array}{l}\text { W węższym znaczeniu kształcenie na rzecz śro- } \\
\text { dowiska zawiera zarówno szkolne i przedszkolne }\end{array}$ \\
związane z ekologia, wspierać ogólną świadomość & wychowanie w dziedzinie ekologii, jak i włącze- \\
konieczności ochrony środowiska oraz stwarzać & nie tematów związanych ze środowiskiem w za- \\
warunki poznawcze i emocjonalne w celu wy- & kres dalszego kształcenia na wszystkich szcze- \\
tworzenia w społeczeństwie i kulturze proekolo- & blach zawodowych. Podstawą takiego założenia \\
gicznych sposobów zachowania. & jest interpretacja rozdziału 36 Agendy 21 (wspie- \\
& ranie edukacji szkolnej, świadomości publicznej \\
& oraz podstawowego i uzupełniającego kształcenia \\
& zawodowego), a także praca wiodącego w tej dzie- \\
& dzinie UNESCO oraz CSD (Comission of Sus- \\
& tainable Development - Komisja ds. Zrównowa- \\
& żonego Rozwoju). \\
\hline
\end{tabular}

Źródło: opracowanie autorów na podstawie: Międzynarodowe zarządzanie środowiskiem, t. 1: Interdyscyplinarne założenia proekologicznego zarządzania przedsiębiorstwem, 2004, A. Kryński (red.), C.H. Beck, Warszawa

Sama wiedza o ochronie środowiska (poziom świadomości ekologicznej) nie wystarczy, aby podjąć działania proekologiczne ukierunkowane na przekształcenie przedsiębiorstwa w jednostkę przyjazną środowisku. Świadomość ekologiczna nabyta w trakcie edukacji proekologicznej powinna przekształcić się w postawy przedsiębiorcze uwzględniające konieczność podejmowania działań na rzecz ochrony środowiska. Istotne jest zatem, aby na każdym poziomie nauczania kształtować postawy przedsiębiorcze, a zarazem proekologiczne. Wysoki poziom świadomości ekologicznej daje możliwość podjęcia takich inicjatyw w przedsiębiorstwie, które dadzą wymierne korzyści ekonomiczne (ograniczenie kosztów) i przyczynią się do ochrony środowiska przyrodniczego. Poziom świadomości ekologicznej ma zatem wpływ na sposób zarządzania przedsiębiorstwem, na styl pracy pracowników; może się przekładać zarówno na wyniki finansowe przedsiębiorstwa, jak i na trudne do zmierzenia korzyści dla środowiska przyrodniczego.

Wcześniej czy później społeczeństwo musi realizować ideę rozwoju zrównoważonego (ekorozwoju), która uznaje nadrzędność wymogów ekologicznych poprzez oszczędną produkcję i konsumpcję. Idea ekorozwoju zakłada bowiem uwzględnianie konsekwencji obecnych działań w przyszłości, i preferowanie takich, które nie zagrażają potrzebom i zdrowiu przyszłych pokoleń.

\section{Literatura}

1. Kobyłko G. (red.), 2000, Proekologiczne zarzqdzanie przedsiębiorstwem, Wydawnictwo AE we Wrocławiu, Wrocław

2. Kryński A. (red.), 2004, Międzynarodowe zarzqdzanie środowiskiem, t. 1: Interdyscyplinarne założenia proekologicznego zarzqdzania przedsiębiorstwem, C.H. Beck, Warszawa 


\section{Pro-ecological Education in Shaping Entrepreneurial Attitudes}

Activation of national economy needs constant education of young people and creating their attitudes, because they are the foundation for growth of future business. In the environment of escalating in globalization understanding of the basis of entrepreneurship and creating of entrepreneurial individuals, as well as society, is essential for every man who wants actively participate in the processes of development of world's civilization. The goal of this article is to point that the education in the area of creating entrepreneurial attitudes should include shaping awareness of the threats related to the dynamic economical growth in the country and all the world. Ecological dangers are considered to be the greatest threats to the chance to the development. So the entrepreneurial man is conscious of the threats, sensitive to ecological problems and sees relationships between economic matters and modern, efficient economy that takes into account wide range of problems of environment protection. 